\title{
Investigation of the Correlation Between Pelvic Anthropometric Measurements and Penile ength of 250 Turkish Boys Aged 0-5 Years
}

\author{
Hakan Akdere, ${ }^{1}$ Ali Yılmaz, ${ }^{2}$ Özcan Arabacl, ${ }^{3}$ Yavuz Özdemir, ${ }^{1}$ Ersan Arda ${ }^{1}$
}

'Department of Urology, Trakya University Faculty of Medicine,

${ }^{2}$ Department of Anatomy, Trakya

University Faculty of Medicine,

${ }^{3}$ Department of Urology, Edirne Selimiye State Hospital; all Edirne, Turkey

Submitted: 18.07.2016 Accepted: 05.09.2016

Correspondence: Hakan Akdere, Trakya Üniversitesi Tıp Fakültesi Hastanesi, Üroloji Anabilim Dalı, Edirne, Turkey

E-mail: hakdere@yahoo.com

Keywords: Stretched penile length; Pelvic anthropometry; penile anatomy.

\begin{abstract}
Objective: In the present study, stretched penile length (SPL) of children aged 0-60 months was measured and relationship to anthropometric parameters of age, height, weight, interspinous distance, and pubic bone height $(\mathrm{PBH})$ was evaluated. Data obtained were compared with results of similar studies.
\end{abstract}

Methods: Total of 250 boys (age range: 0-60 months) participated in the study. All measurements of SPL, weight, height, interspinous distance, and $\mathrm{PBH}$ were conducted by single urologist. These assessments were performed under optimal conditions.

Results: Overall mean height of the children was $55.82 \pm 3.22 \mathrm{~cm}$, mean weight was $4729.08 \pm 54.23 \mathrm{~g}$, mean interspinous distance was $12.757 \pm 1.21 \mathrm{~cm}$, mean $\mathrm{PBH}$ was $2.56 \pm 0.46$ $\mathrm{cm}$, and mean SPL was $2.69 \pm 0.57 \mathrm{~cm}$. Relationship between SPL and age, weight, height, and interspinous distance was statistically significant $(r=0.240, p=0.00 \mathrm{I} ; r=0.242, p=0.00 \mathrm{I}$; $r=0.204, p=0.006 ; r=0.224, p=0.002$, respectively). Relationship between SPL and PBH was not statistically significant $(r=0.97, p=0.191)$.

Conclusion: Correct evaluation of penis size abnormality requires both knowledge of age and origin-specific average SPL values and analysis of these data. Present study provides current reference values for Caucasian boys aged 0-60 months. When combined with anthropometric measurements, these data may be beneficial to clinicians in diagnosis and treatment process.

\section{INTRODUCTION}

Genital examination of a newborn is of utmost importance in determination of gender and detection of underlying conditions, such as urogenital anomalies, congenital adrenal hyperplasia, hypothalamicpituitary failure, or genetic disease. ${ }^{[l]}$ Early detection of these pathologies during neonatal period may be life-saving.

One of the most important aspects of genital examination of a newborn is presence of micropenis. ${ }^{[2]}$ If stretched penile length (SPL) is average of $2.5 \mathrm{SD}$ below age-matched penile length, it is accepted as micropenis. ${ }^{[3]}$ Micropenis is usually associated with testicular anomalies and anomalies of external genitalia. If this pathology is not detected at an early stage and treatment not planned appropriately, it can lead to various metabolic, psychological, or sexual disorders, and may become a social problem at later stage. ${ }^{[4]}$

Average penile length and standard values have been determined in various studies. In daily clinical practice, these standard measurements are used for patient examinations. In recent studies, different average penile lengths according to ethnic origin and race have been reported. Therefore, 
standardized penile lengths are being questioned, and replaced by the concept of evaluation of penile length according to ethnic origin. ${ }^{[4]}$ In a scientific study performed in China, average penile length of the infants born in the study area was found to be shorter than that of the white race. ${ }^{[5]}$

Anthropometry is a branch of science that examines dimensions of human body. Some reference points have been determined to standardize anthropometric measurements. These measurements are made by bending, rotating, or stretching the body from a fixed position and measuring the greatest distance reached. The science that deals with structural measurements of the body is static anthropometry, while dynamic anthropometry is concerned with functional measurements. ${ }^{[6]}$

In recent years, increase in publications on disorders of male reproductive health is noteworthy. In these publications, decrease in sperm quality; genital anomalies, such as hypospadias, epispadias, and undescended testis; and incidence of testicular cancer have frequently been reported. Environmental endocrine disrupters have been suggested as the most important factors leading to adverse developments. A baby born today is exposed to larger quantity of chemical substances beginning during intrauterine life compared with those born during 1940s, and consumption of natural foods typically decreases as he grows older. Every day, deleterious effects of environmental endocrine disrupters on human beings are increasing at higher rates and becoming more prominent. ${ }^{[7]}$

Current study provides measurement data of SPL of children aged 0-60 months and evaluation of its relationship to anthropometric measurements of age, height, body weight, interspinous distance, and pubic bone height $(\mathrm{PBH})$. We compared our results with SPL values obtained in studies performed with children of different races and ethnicities.

\section{PATIENTS AND METHODS}

Present cross-sectional study was conducted with 250 male children aged between 0 and 60 months who were admitted to state hospital between June and October, 2010, or to university hospital between April and October, 2013. Study was approved by the ethics committee of the Trakya University. Children with penile abnormalities (e.g., phimosis, hypospadias, epispadias, or concealed penis), varicocele, undes- cended testis, or diseases that might result in developmental or growth retardation (e.g., chronic renal failure, endocrine disorders) were excluded. Majority of our study group of 250 patients consisted of those who were presented at outpatient clinic for periodic check-ups and those presented at urology clinics for urinary system infection.

Single urologist determined and recorded age, SPL, height, body weight, interspinous distance, and $\mathrm{PBH}$ of the children. All measurements were performed in company of a member of boy's family in a ventilated room at room temperature varying between $23^{\circ} \mathrm{C}$ and $25^{\circ} \mathrm{C}$. SPL was measured with a ruler. One end of the ruler was held to adipose tissue covering pubic ramus and distance to most distal end of the external meatus was measured. ${ }^{[8-10]}$ Foreskin was not taken into account. Circumcised children were not included in the study. SPL of each child was measured twice, and average of these 2 values was recorded. Distance between anterior superior iliac spines was recorded as interspinous distance.

For statistical analysis of data, NCSS 2007 (NCSS, LLC, Kaysville, UT, USA) software was used. Descriptive statistical methods (mean, SD), SPL, and anthropometric measurements (height, body weight, interspinous distance, and $\mathrm{PBH}$ ) were compared using Pearson's correlation coefficient. Results were evaluated within $95 \%$ confidence interval and $p<0.05$ was accepted as level of statistical significance.

\section{RESULTS}

Based on study results, mean height and weight of the children were $55.82 \pm 3.22 \mathrm{~cm}$ and $4729.08 \pm 54.23$ $g$, respectively. Mean interspinous distance and $\mathrm{PBH}$ were recorded as $12.757 \pm 1.21 \mathrm{~cm}$ and $2.56 \pm 0.46 \mathrm{~cm}$, respectively. Mean SPL was found to be $2.69 \pm 0.57$ $\mathrm{cm}$.

If SPL was average of 2.5 SD below age-matched mean penile length, it was defined as micropenis and not included in the study.

Marked correlation was found between SPL and age, body weight, height, and interspinous distance $(r=0.240, p=0.00 I ; r=0.242, p=0.001 ; r=0.204$, $p=0.006 ; r=0.224, p=0.002$, respectively). Findings are presented in Figures $I$ and 2. No significant correlation was found between SPL and PBH $(r=0.97$; $\mathrm{p}=0.191$ ). 


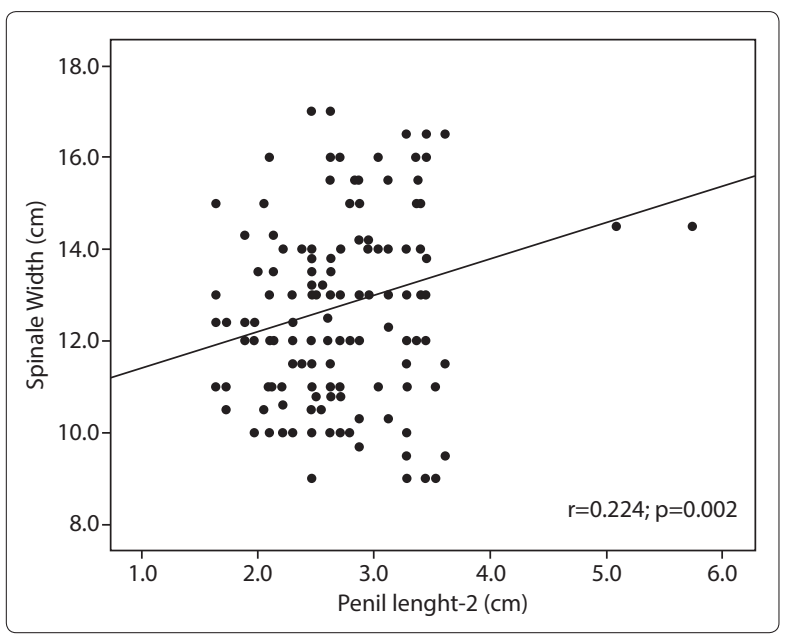

Figure 1. A significant correlation was detected between stretched penile length and interspinous distance.

\section{DISCUSSION}

Male external genitalia originate and develop from genital tubercle during intrauterine period. Hypothalamic-pituitary-gonadal axis stimulates development of penis from genital tubercle at 8 to 14 weeks of intrauterine life. Penile growth is at its maximum rate ( $4 \mathrm{~cm} /$ year) between 20 gestational weeks and birth. This rapid development depends on stimulation of HPG axis. During first 3 months after birth (minipuberty period) penile length increases rapidly in parallel with increase in testosterone level. Penis continues to grow at a slower rate with total increase in penile length of I to $2 \mathrm{~cm}$ between I and 7 years of age. ${ }^{[3,11,12]}$

Accurate measurement of penile length in children is of great importance. Abnormality affecting penile length may signal presence of serious disease. Various methods of measurement are available. Method described by Schonfeld in 1942 is still considered optimal. ${ }^{[10]}$ According to Schonfeld's method, measurement is performed with a ruler. Adipose tissue on pubic ramus is depressed and retracted, and the penis is stretched to full length. Distance between extreme point of the penile glans and pubis is measured. Alternative measurement tools, such as $10 \mathrm{cc}$ syringe, have been reported in various studies; however, incorrect mesurement can result due to suprapubic adipose tissue.

In the present study, 2 items were emphasized. SPL and relationship of SPL to anthropometric measurements and determination of average SPL of children in this geographic region.

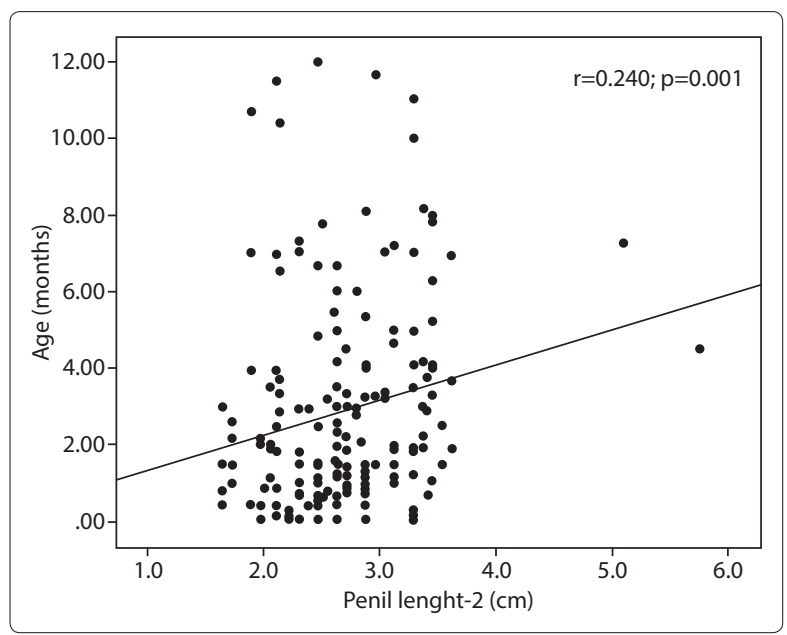

Figure 2. A significant correlation was detected between stretched penile length and age.

Significant correlation between SPL and age, body weight, and height was observed. Literature review of this subject revealed comparable results.

We wanted to examine relationship between SPL and pelvic anthropometric distances in particular, as it has not yet been presented in the literature. in the literature. Significant correlation was found between SPL and interspinous distance; however, no significant correlation was seen between SPL and PBL.

In studies performed on infants of same race and ethnicity, differences of up to $0.5 \mathrm{~cm}$ were seen in mean SPL values. In our literature review, we encountered greatest difference in SPL in 2 studies performed in region of South India. In 2 postnatal studies performed on newborns, median SPL was $2.3 \mathrm{I} \mathrm{cm}$ and 3.57 $\mathrm{cm} .{ }^{[13,14]}$ Mean SPL value in studies of newborns of different races and ethnicities may vary widely. ${ }^{[3,11]}$ For example, mean SPL of Chinese children was found to be lower than that reported for Caucasians and even other Asian ethnicities. If a Chinese boy is not evaluated based on mean SPL measurements specific to his population, he may be mistakenly diagnosed with micropenis. ${ }^{[15]}$ In summary, median SPL measurement of children of diverse races and ethnicities reported in various literature studies has ranged from $2.31 \mathrm{~cm}$ to $3.75 \mathrm{~cm} \cdot{ }^{[10,15-20]}$

In gold-standard study by Schonfeld and Beebe, ${ }^{[10]}$ mean SPL was $3.75 \pm 0.3 \mathrm{~cm}$, while Feldman and $S i^{\left[2 h^{[2]}\right.}$ and Flatau et al. reported mean SPL measurements of $3.5 \pm 0.7 \mathrm{~cm}$ and $3.5 \pm 0.4 \mathrm{~cm}$, respectively. [22] In studies performed in various Asian countries, including Singapore and Saudi Arabia, comparable 
mean SPLs were obtained. ${ }^{[14-17]}$ However, markedly lower mean SPL has been reported in studies performed on babies born in Indonesia, China, and Japan. ${ }^{[18-20]}$

In a study by Fok et al. ${ }^{[20]}$ performed with Chinese children, significant correlation was found between SPL and body weight, height, and gestational age. This strong correlation may explain why average SPL of Chinese children with lower average height and weight is relatively shorter when compared with SPL of other ethnicities. In summary, average SPL varies between races and ethnic origins based on different average body weight and height of children, as well as other factors. ${ }^{[23]}$

\section{Conclusion}

Accurate evaluation of penile length requires knowledge about age- and ethnicity-specific average SPL values, and penile examination for abnormalities should be performed with the support of this information. Otherwise, child with completely normal penile length may be mistakenly diagnosed as having micropenis. Our study has provided current reference values for Caucasian children. Study results evaluated in combination with anthropometric measurements may be useful to clinicians during phases of diagnosis and treatment. Furthermore, present study sets an example for larger-scale studies performed using older patient population in a larger geographic region.

Conflict of interest

None declared.

\section{REFERENCES}

1. Guo LL, Tang DX. Measurement of penile length in children and its significance. Zhonghua Nan Ke Xue 2013;19:83540.

2. Da Silva EA, Schiavini J, Yang S, Miranda M, Damião R. Health-related quality of life of patients who underwent multiple surgeries for penile diseases. J Sex Med 2004;1:80.

3. Lee JH, Ji YH, Lee SK, Hwang HH, Ryu DS, Kim KS, et al. Change in penile length in children: preliminary study. Korean J Urol 2012;53:870-4.

4. Aaronson IA. Micropenis: medical and surgical implications. J Urol 1994;152:4-14.

5. Smith DP, Rickman C, Jerkins GR. Ultrasound evalua- tion of normal penile (corporeal) length in children. J Urol 1995;154:822-4.

6. Perovic SV, Djordjevic ML. Penile lengthening. BJU Int 2000;86:1028-33.

7. Shamloul R. Treatment of men complaining of short penis. Urology 2005;65:1183-5.

8. Camurdan $\mathrm{AD}, \mathrm{Oz}$ MO, Ilhan MN, Camurdan OM, Sahin F, Beyazova U. Current stretched penile length: cross-sectional study of 1040 healthy Turkish children aged 0 to 5 years. Urology 2007;70:572-5.

9. Cinaz P, Yeșilkaya E, Onganlar YH, Boyraz M, Bideci A, Camurdan O, et al. Penile anthropometry of normal prepubertal boys in Turkey. Acta Paediatr 2012;101:33-6.

10. Schonfeld WA, Beebe GW. Normal growth and variation in the male genitalia from birth to maturity. J Urol 1942;48:759-77.

11. Boas M, Boisen KA, Virtanen HE, Kaleva M, Suomi AM, Schmidt IM, et al. Postnatal penile length and growth rate correlate to serum testosterone levels: a longitudinal study of 1962 normal boys. Eur J Endocrinol 2006;154:125-9.

12. Smith DP, Rickman C, Jerkins GR. Ultrasound evaluation of normal penile (corporeal) length in children. J Urol 1995;154:822-4.

13. Kulkarni ML, Rajendran NK. Normal values for penile standards in newborns. Indian Pediatr 1991;28:1341-3.

14. Vasudevan G, Manivarmane, Bhat BV, Bhatia BD, Kumar S. Genital standards for south Indian male newborns. Indian J Pediatr 1995;62:593-6.

15. Ozbey H, Temiz A, Salman T. A simple method for measuring penile length in newborns and infants. BJU Int 1999;84:1093-4.

16. Al-Herbish AS. Standard penile size for normal full term newborns in the Saudi population. Saudi Med J 2002;23:314-6.

17. Lian WB, Lee WR, Ho LY. Penile length of newborns in Singapore. J Pediatr Endocrinol Metab 2000;13:55-62.

18. Sutan-Assin M, Rukman J, Dahlan A. Penile dimensions of newborn infants. Paediatr Indones 1989;29:146-50.

19. Fujieda K, Matsuura N. Growth and maturation in the male genitalia from birth to adolescence. II. Change of penile length. Acta Paediatr Jpn 1987;29:220-3.

20. Fok TF, Hon KL, So HK, Wong E, Ng PC, Chang A, et al. Normative data of penile length for term Chinese newborns. Biol Neonate 2005;87:242-5.

21. Feldman KW, Smith DW. Fetal phallic growth and penile standards for newborn male infants. J Pediatr 1975;86:3958.

22. Flatau E, Josefsberg Z, Reisner SH, Bialik O, Iaron Z. Letter: Penile size in the newborn infant. J Pediatr 1975;87:663-4.

23. Cheng PK, Chanoine JP. Should the definition of micropenis vary according to ethnicity? Horm Res 2001;55:278-81. 


\section{O-5 Yaş Arası 250 Türk Çocukta Penis Uzunluğu ile Pelvik Antropometrik Ölçümler Arasındaki Korelasyonun Araştırılması}

Amaç: Çalışmamızda 0-60 ay arası çocukların gerilmiş penis uzunluğu (GPU) ölçüldü ve yaş-boy-kilo-interspinöz mesafe ve pubis yüksekliği gibi antropometrik parametrelerle ilişkisi değerlendirildi. Elde ettiğimiz veriler, benzer diğer literatür çalışmaları ile karşılaştırıldı.

Gereç ve Yöntem: Çalışmamız, 0-60 ay yaş arası 250 erkek çocukta yapıldı. Bütün çocukların gerilmiş penis uzunluğu, kilosu, boyu, interspinöz mesafesi ve pubis yüksekliği tek bir ürolog tarafından değerlendirildi. Bu değerlendirmeler optimal poliklinik şartlarında gerçekleştirildi.

Bulgular: Çocukların ortalama boyu $55.82 \pm 3.22 \mathrm{~cm}$, ortalama vücut ağırlığı $4729.08 \pm 54.23 \mathrm{gr}$, ortalama interspinöz mesafesi I2.757 \pm I.2I $\mathrm{cm}$, ortalama pubis yüksekliği $2.56 \pm 0.46 \mathrm{~cm}$, GPU $2.69 \pm 0.57 \mathrm{~cm}$ olarak ölçüldü. Gerilmiş penis uzunluğu ile çocukların yaşı, ağılığı, boyu ve interspinöz mesafesi arasında belirgin bir ilişki bulundu (sırasıyla: $r=0.240, p=0.001 ; r=0.242, p=0.00 I ; r=0.204, p=0.006 ; r=0.224, p=0.002$ ). GPU ve pubis yüksekliği arasında anlamlı bir ilişki bulunmadı $(r=0.97, p=0.191)$.

Sonuç: Penis uzunluğundaki anomalileri doğru değerlendirebilmek için yaşa ve ırka özgü ortalama GPU değerleri bilinip, bu veriler göz önünde tutularak muayene yapılmalıdır. Çalışmamız 0-60 ay yaş aralığındaki beyaz ırk çocuklar için güncel referans değerler sağlamıştır. Antropometrik ölçümlerle birlikte değerlendirildiğinde bu veriler klinisyenlere tanı ve tedavi süreci aşamalarında yararlı olabilir.

Anahtar Sözcükler: Gerilmiş penis uzunluğu; pelvik antropometri; penis anatomisi. 